\title{
Towards a regional beef carcass classification system for Southern Africa
}

\author{
G.Chingala ${ }^{1,2}$, E. Raffrenato ${ }^{1}$, K. Dzama ${ }^{1}$ L.C. Hoffman ${ }^{1}$ \& C. Mapiye ${ }^{1 \#}$ \\ ${ }^{1}$ Department of Animal Sciences, Stellenbosch University, Private Bag X1, Matieland 7602, South Africa \\ ${ }^{2}$ Lilongwe University of Agriculture and Natural Resources, P.O. Box 219, Lilongwe, Malawi
}

(Received 17 February 2017; Accepted 6 April 2017; First published online 15 May 2017)
Copyright resides with the authors in terms of the Creative Commons Attribution 4.0 South African Licence.
See: http://creativecommons.org/licenses/by/4.0/za
Condition of use: The user may copy, distribute, transmit and adapt the work, but must recognise the authors and the South African Journal of Animal Science.

\begin{abstract}
Southern Africa is home to over 64 million cattle, of which $75 \%$ are raised on natural pasture in smallholder farming areas. Indigenous cattle breeds Bos indicus (zebu), B. taurus africanus (Sanga type) and their crosses with $B$. taurus (European and British) are the most dominant. Despite their dominance, indigenous cattle breeds in smallholder farming areas are commonly marketed through informal markets, and their contribution to formal national economies is therefore limited. This is partly because the current beef carcass grading and classification systems used in the region value inappropriately carcasses from slow-maturing indigenous cattle breeds that are ideally suited to being marketed off natural pasture. The existing systems use carcass yield and quality attributes, but do not predict eating quality at consumer level. Moreover, the principal criteria used to estimate carcass yield and quality, namely age, fat cover and conformation, are assessed indirectly and subjectively. The objective of the current review is to provide an overview of beef carcass grading and classification systems in Southern Africa and analyse their shortcomings in valuing carcasses from indigenous breeds and local production systems. In addition, the review highlights opportunities for improving these systems in Southern Africa and makes suggestions towards developing a regional beef carcass classification system.
\end{abstract}

Keywords: beef, carcass grading and classification, indigenous cattle, smallholder farming

\#Corresponding author: cmapiye@sun.ac.za

\section{Introduction}

Southern Africa is the southernmost region of the African continent geopolitically, comprising twelve mainland countries (Angola, Botswana, Democratic Republic of Congo, Lesotho, Malawi, Mozambique, Namibia, South Africa, Swaziland, Tanzania, Zambia and Zimbabwe) and three island ones (Madagascar, Mauritius and Seychelles), located mainly between latitudes $4^{\circ}$ to $35^{\circ}$ south and longitudes $12^{\circ}$ to $58^{\circ}$ east (FAO, 2007). These 15 countries make up a regional economic body known as the Southern African Development Community (SADC). The region is home to over 64 million cattle, of which $75 \%$ are kept under smallholder farming systems that rely on natural pasture (SADC, 2012). Natural pasture constitutes over $60 \%$ of the region's total land area (FAO, 2007). Indigenous Bos indicus (zebu) and B. taurus africanus (Sanga) and their nondescript crosses with exotic B. taurus (European and British) are the dominant cattle breeds (Strydom, 2008). Indigenous cattle are slow maturing and ideally suited to being marketed off natural pasture (Strydom et al., 2015). Natural pasture-fed indigenous cattle often achieve the required levels of finish at lighter weights and older age than early maturing exotic breeds, which are suitably finished on grain. Such older and lighter carcasses from indigenous cattle fetch low prices in formal markets. This is mainly because grading and classification systems in formal markets favour heavy carcasses from young animals, which are usually obtained from grain-fed exotic breeds (Webb, 2015; Strydom et al., 2015).

Grading and classification systems are used in the beef industry to describe the quality and yield of a carcass to ensure consistent meat quality and consumer satisfaction (Allen, 2014; Aalhus et al., 2014). The terms 'grading' and 'classification' do not have the same meaning. On the one hand, grading refers to the placing of different values on several carcass attributes and using combinations of these attributes to develop a grade that relates to meat quality for pricing purposes, depending on the market and requirements of traders and consumers (Allen, 2014). On the other hand, carcass classification refers to the sorting of carcasses with similar attributes into classes based on certain criteria to guide those involved in the production, trading, and consumption of carcasses (Aalhus et al., 2014). Overall, in carcass classification the emphasis is on providing the beef industry and consumers with a choice of types of carcasses in terms of 
carcass composition and physical attributes, while there is no indication of perceived quality, as is provided in a grading system (Webb, 2015; Strydom, 2011).

Beef carcass grading and classification systems used in Southern Africa are becoming less useful because of considerable increases in variation in their categories (Strydom et al., 2015), mainly because of differences among cattle breeds and production systems, and the use of modern feedstuffs and growthenhancing technologies (Strydom, 2011). Furthermore, these systems do not always include eating quality standards, particularly beef palatability (Webb, 2015). In reality, most systems in southern Africa (Webb, 2015; Strydom, 2011) and the world at large (Polkinghorne \& Thompson, 2010) are indicators of cattle finishing or fatness and meat yield rather than beef palatability at consumer level. Moreover, most of the descriptive terms used in the current systems are vague, subjective and sometimes meaningless. Consequently, there is growing interest in Southern Africa in establishing systems that correspond with the diverse beef breeds and production systems, and are in tune with local consumer preferences. The current review summarizes grading and classification systems used in Southern Africa, examines their strengths and weaknesses in valuing carcasses of indigenous breeds finished off pasture, and makes recommendations for the development of an inclusive classification system for the region.

\section{Beef production and marketing systems in Southern Africa}

Beef production in Southern African countries is divided into commercial (freehold) and smallholder (traditional) sectors (Naziri et al., 2015; Soji et al., 2015). The commercial sub-sector is well developed, capital intensive, and export oriented (Cabrera et al., 2010). Commercial beef production is stratified into extensive (ranching) and intensive (feedlot) systems, with herd sizes varying between 1000 and 30000 cattle, although a few feedlot systems have larger numbers of cattle at any one period, made up mostly of British and European breeds and their crosses with indigenous breeds (Strydom, 2008; Ransom, 2011; Haasbroek, 2013). Pure indigenous cattle breeds are shunned by feedlots because they often fail to meet feedlot induction specifications for weight, fatness, age, and frame score (Strydom, 2008). With the exception of South Africa, feedlot systems in Southern African countries are not fully developed, and beef is mostly derived from cattle finished off natural pasture (Ransom, 2011; Dzanja et al., 2013; Maciel et al., 2015). In South Africa, feedlot beef production accounts for over $80 \%$ of the national beef value chain, and parallels some developed countries (Webb \& Erasmus, 2013). Weaner producers in Southern Africa in general supply steers or bulls to feedlots at six to twelve months, with induction weights between 180 and $250 \mathrm{~kg}$ (Strydom, 2008). These steers or bulls are then finished on a high-energy grain-based diet for 60 to 150 days. Alternatively, steers are backgrounded on natural pasture or forage-based diets for one to three years before entering the feedlot (Webb \& Erasmus, 2013).

Smallholder beef production is subdivided into small-scale (subsistence-cum-commercial) and communal (subsistence) systems (Naziri et al., 2015; Soji et al., 2015). Natural pasture is the major feed resource for cattle in the smallholder sector (Mapiye et al., 2009; Dzanja et al., 2013). Cattle are usually offered for sale at three years or older on an ad hoc basis (Ransom, 2011; Soji et al., 2015). A large proportion of the cattle kept in smallholder areas are tropical indigenous breeds and their nondescript crosses with exotic breeds (Strydom, 2008). The major indigenous cattle breeds in Southern Africa are Bos indicus (zebu) (e.g. Angoni and Malawi zebu) and B. taurus africanus (Sanga type) (e.g. Afrikaner, Mashona, Nguni, Tuli and Tswana). Zebu cattle are found mostly north-east of the Zambezi River (Malawi, Mozambique and Zambia). Sanga cattle are found predominately to the south of the Zambezi in Angola, Botswana, Namibia, South Africa and Zimbabwe.

The parallelism exhibited in beef production systems in Southern Africa is also evident in beef marketing (Marandure et al., 2016). The commercial sector sells its beef through formal markets, while the smallholder sector sells through informal (unlicensed) markets. In formal markets, cattle are marketed through abattoirs to wholesalers, retailers, processors, and specialized butcheries (Soji et al., 2015). At the abattoir, quality assurance schemes, including carcass grading and classification systems, are used to determine meat prices. In the informal markets, cattle are marketed directly from farmer to farmer or to local butcheries, speculators, and auctioneers (Musemwa et al., 2010). Here, the prices are determined visually, based on frame size and live weight. Under current grading and classification systems in Southern Africa, indigenous cattle breeds, especially those finished off natural pasture, often fail to achieve the best classes and grades owing to their light weight, lack of subcutaneous fat, and old age (Strydom et al., 2015). Light and old animals fetch lower prices per kilogram in the formal sector (Soji et al., 2015). This drives smallholder farmers away from marketing indigenous cattle through formal markets. Interestingly, there is a segment of beef consumers in Southern Africa that prefer older animals finished off pasture, especially among black African communities (Thompson et al., 2010; Ransom, 2011). Furthermore, a number of ventures in Southern Africa that are funded by governments and development agents seek to promote beef production from indigenous breeds in the smallholder sector. The success of these programmes hinges on 
the development of a new classification system that can offer best rewards for older animals finished off pasture. A clear description of important carcass and meat traits is therefore the first step towards improved beef production in the region. It is therefore crucial to reform current grading and classification systems to promote slow-maturing indigenous cattle marketed off natural pasture. This could be done by marketing pasture- and grain-finished beef separately as unique products in the same classification system to cater for different consumer preferences. This could create an opportunity for smallholder farmers to gain a share of lucrative formal markets, which are currently dominated by young feedlot-finished carcasses from exotic breeds produced by commercial farmers.

\section{Selected beef carcass grading and classification systems in Southern Africa}

The origins and evolution of the major grading and classification systems of the world, including Australian Meat Standards (MSA), Canadian beef grading system, EUROP classification system, Japanese grading standards, and United States Department of Agriculture (USDA) grading system are well published (Polkinghorne \& Thompson, 2010; Allen, 2014). The majority of grading and classification systems in Southern Africa (Table 1), like other developing countries, apply similar schemes to or derivatives of the world's major systems (Allen, 2014). The grading and classification schemes in Southern African countries emphasize carcass maturity (age), fat cover and conformation (Malawi Meat \& Meat Products Act, 1985; South African Meat Industry Company (SAMIC), 2006; Botswana Livestock \& Meat Industries, 2007; Zimbabwean Carcass Classification \& Grading Regulations, 2016). With the exception of South Africa and Namibia, information describing beef carcass grading and classification schemes in Southern African countries is limited. The principal grading and classification criteria used in selected Southern African countries are summarized in Table 1.

Table 1 Principal components of beef carcass grading and classification schemes in selected countries in Southern Africa

\begin{tabular}{|c|c|c|c|c|}
\hline Country & Botswana & Malawi & $\begin{array}{l}\text { Namibia and South } \\
\text { Africa }\end{array}$ & Zimbabwe \\
\hline Grading or classification unit & Carcass & Carcass & Carcass & Carcass \\
\hline Classification system & - & - & Yes & Yes \\
\hline Grading system & Yes & Yes & - & - \\
\hline & Carcass weight & Carcass weight & Carcass weight & Carcass weight \\
\hline & Dentition & Dentition & Dentition & Dentition \\
\hline Attributes appraised on the & & Gender & Gender & Gender \\
\hline slaughter floor & Fat cover & & Fat cover & Fat cover \\
\hline & Conformation & & Conformation & Conformation \\
\hline & Carcass bruising & & Carcass bruising & Carcass bruising \\
\hline & & & & Bone ossification \\
\hline \multirow{7}{*}{$\begin{array}{l}\text { Attributes appraised on the chilled } \\
\text { carcass }\end{array}$} & & $\begin{array}{l}\text { Cold carcass } \\
\text { weight }\end{array}$ & & \\
\hline & & Conformation & & \\
\hline & & Marbling score & & \\
\hline & & Fat cover & & \\
\hline & Fat colour & Fat colour & & \\
\hline & & Bone ossification & & \\
\hline & & Carcass bruising & & \\
\hline
\end{tabular}

Grading and classification systems in Southern Africa are applied voluntarily in licensed registered slaughter facilities. Despite carcass grading and classification being applied on this basis, most retailers and wholesalers prefer classified meat as a guarantee of product quality, in line with consumer demands (Strydom et al., 2015). 
Botswana uses a grading system to distinguish beef carcasses, which are graded into hierarchical quality grades of prime, super, first, second, third, fourth and canning. Grading is based on carcass maturity (dentition), and subjective scores of degree of subcutaneous fat distribution, conformation, bruising, fat cover and colour (Botswana Livestock \& Meat Industries, 2007). Beef carcasses showing signs of staginess, overfatness, and bruising may be graded one or more grades lower than the one for which they would have qualified. Prime grade is placed on carcases of either sex with no more than two permanent incisors of good conformation with uniform light fat cover and white fat. Super grade is obtained from animals of either sex with no more than four permanent incisors, of good conformation with uniform light fat cover, and white fat. Carcasses with no more than four permanent incisors, but patchy fat cover, or those with five to eight permanent incisors, of good conformation with uniform light fat cover and white or creamy fat, are ranked first grade. The carcasses of either sex with up to eight permanent incisors, of fair conformation with uniform light fat cover, and fat of any normal colour, are assigned to second grade. Third grade is given to carcasses of any sex and age, of poor conformation and no fat cover. Fourth grade is placed on carcasses of any sex and age of very poor conformation and patchy or no fat cover. Canning grade is given to carcasses of any sex and age of very poor conformation with oedema.

Similar to Botswana, Malawi uses a grading system. The criteria in Malawi are carcass maturity (dentition and bone ossification), cold carcass weight, fat cover, fat colour, marbling, conformation, bruising and gender (Malawi Meat \& Meat Products Act, 1985). The Malawian grading system divides carcass maturity into two age groups: zero-six permanent incisors, and more than six. Bone ossification, an additional criterion used to assess carcass maturity, is determined visually by the presence or absence of ossification in the spinal process of the lumbar region of carcasses with more than six permanent incisors. Marbling at the twelfth rib is scored visually into three classes: liberal, fair and poor. Beef carcasses are graded into five quality grades of choice, prime, standard, commercial, and inferior. Choice grade is placed on carcasses derived from steers or heifers with not more than six permanent incisors and weighing not less than $180 \mathrm{~kg}$ (cold carcass weight). In addition, choice grade carcasses must have a good conformation with plump, well-fleshed quarters, an even covering of firm white or creamy-white fat, well-developed kidney and channel fat, and a liberal distribution of marbling at the point of quartering. The carcasses must be free from objectionable bruises and taint, and be bright and sound in condition. Carcasses of young bulls qualify for choice grade if they have no permanent incisors and meet all other requirements of that grade. Prime grade is assigned to carcasses derived from steers or heifers with seven-eight permanent incisors, which do not show any pronounced ossification of the spinal processes in the lumbar region, and weighing not less than $146.25 \mathrm{~kg}$ cold carcass weight after 24 hours' refrigeration. The quarters must be plump and well fleshed, but the development of internal and external fat may be somewhat less than in the choice grade. The carcasses must have a fair distribution of marbling at the point of quartering (twelfth rib). Carcasses must be free from objectionable bruises and taint, and be bright and sound in condition. Standard grade is given to carcasses from steers, cows, and bulls of any age, moderately fleshed, and covered with fat, except for bulls. Bulls should be well covered with fat. Commercial grade is given to carcasses harvested from steers, cows and bulls of any age, fairly fleshed, and covered with some fat. Inferior grade is given to steers, cows and bulls below the standard grade. The use of quality grade names such as 'inferior' in the current grading system may have negative connotations tor retailers and consumers. Use of non-discriminatory terms such as 'canning' and 'manufacturing' grade, as adopted in the Botswana grading system, which corresponds to the Malawian inferior grade, may be more appropriate.

Namibia and South Africa use a classification system to describe beef carcasses. Owing to their common geopolitical history, Namibia and South Africa have the same carcass classification system (SAMIC, 2016). According to South African Government Notice No. 38431 of 2015 and the Meat Board Namibia, beef carcasses are classified based on age, fat cover, conformation, carcass damage and gender (Table 2). However, age and fat cover are the major criteria (Strydom, 2011). Age is categorised into four classes, as shown in Table 2. Beef bulls in age classes $B$ and $C$ are marked 'MD' to distinguish them from young beef bulls in $A$ and $A B$ classes. Fat cover is assessed objectively through subcutaneous backfat depth measured $5 \mathrm{~cm}$ laterally from the mid-line cut on the ninth rib, and carcasses are assigned to one of seven classes as shown in Table 2. Conformation is classified into five classes, while carcass damage is categorized into three classes (Table 2). 
Table 2 South African and Namibian beef carcass classification system

\begin{tabular}{|c|c|}
\hline Classification & Description \\
\hline \multicolumn{2}{|l|}{ Age } \\
\hline 0 permanent incisors & $A$ \\
\hline 1-2 permanent incisors & $A B$ \\
\hline 3-6 permanent incisors & $\mathrm{B}$ \\
\hline$>6$ permanent incisors & $\mathrm{C}$ \\
\hline \multicolumn{2}{|l|}{ Fat cover } \\
\hline 0 & No fat (0 mm fat thickness) \\
\hline 1 & Very lean $(0.1-0.9 \mathrm{~mm}$ fat thickness) \\
\hline 2 & Lean (1.0-3.0 mm fat thickness) \\
\hline 3 & Medium (>3.0- $\leq 5.0 \mathrm{~mm}$ fat thickness) \\
\hline 4 & Fat (5.0- $\leq 7.0 \mathrm{~mm}$ fat thickness) \\
\hline 5 & Very fat $(>7.0-\leq 10.0 \mathrm{~mm}$ fat thickness) \\
\hline 6 & Excessively fat (>10 mm fat thickness) \\
\hline \multicolumn{2}{|l|}{ Conformation } \\
\hline 1 & Very flat \\
\hline 2 & Flat \\
\hline 3 & Medium \\
\hline 4 & Round \\
\hline 5 & Very round \\
\hline \multicolumn{2}{|l|}{ Carcass damage } \\
\hline 1 & Slight \\
\hline 2 & Moderate \\
\hline 3 & Severe \\
\hline \multicolumn{2}{|l|}{ Gender } \\
\hline \multicolumn{2}{|c|}{ Only beef bulls in age class B and C are marked 'MD' } \\
\hline
\end{tabular}

The Zimbabwean beef industry moved recently from a carcass grading system to a new carcass classification system (Zimbabwean Carcass Classification \& Grading Regulations, 2016). Under the new system, beef carcasses are classified based on maturity (age), fat cover, conformation, gender and bruising (Table 3). In terms of age, carcasses are categorized into three classes (Table 3) according to the number of erupted permanent incisor teeth in young cattle and the degree of spinal ossification in carcasses of fullmouth cattle. Fat cover is assessed objectively through subcutaneous backfat depth measured $5 \mathrm{~cm}$ laterally from the midline cut between 10th and 11th ribs and carcasses are allotted to one of five classes as shown in Table 3. Carcass conformation is divided visually into five classes (Table 3). Carcasses of male cattle that show the development of secondary male sex characteristics, and signs of late castration are marked with a code 'MD'. Carcass bruising classification is done by estimating the trimmed meat weight loss as a percentage of carcass weight. Damage is categorised into four classes (Table 3). Calf carcasses are classified according to age and weight and codified 'CALF'. Calf carcass conformation and damage are classified as for mature cattle carcasses. 
Table 3 Zimbabwean beef carcass classification system

\begin{tabular}{|c|c|}
\hline Classification & Description \\
\hline \multicolumn{2}{|l|}{ Age } \\
\hline 0-2 permanent incisors & $A$ \\
\hline 3-6 permanent incisors & $\mathrm{B}$ \\
\hline 7-8 permanent incisors & $\mathrm{C}$ \\
\hline \multicolumn{2}{|l|}{ Fat cover } \\
\hline 0 & No measurable fat (0 mm fat thickness) \\
\hline 1 & Slight fat cover (1-2 mm fat thickness) \\
\hline 2 & Medium fat cover (3-6 mm fat thickness) \\
\hline 3 & Slightly over fat 7-12 mm fat thickness) \\
\hline 4 & Excessive fat cover (>13 $\mathrm{mm}$ fat thickness) \\
\hline \multicolumn{2}{|l|}{ Conformation } \\
\hline 1 & Very flat \\
\hline 2 & Flat \\
\hline 3 & Medium \\
\hline 4 & Round \\
\hline 5 & Very round \\
\hline \multicolumn{2}{|l|}{ Gender } \\
\hline \multicolumn{2}{|c|}{ Only beef bulls in Age Class B and C are marked 'MD' } \\
\hline \multicolumn{2}{|l|}{ Bruising } \\
\hline 1 & The code is shown on one side to indicate that the other side is unbruised \\
\hline 2 & The code appears on both sides indicating that bruising is $<2 \%$ of the carcass weight \\
\hline 3 & The code indicates that both sides were trimmed by $>2 \%$ of the carcass weight \\
\hline 4 & The code denotes trimming caused by abscesses, infected wounds and injections \\
\hline
\end{tabular}

\section{Shortcomings of the current beef carcass grading and classification systems in Southern Africa}

Overall, grading and classification systems in Southern Africa use similar criteria, which emphasize animal age, fat cover and conformation. They also use carcass yield and quality attributes to infer beef palatability. Fisher (2007) noted that it is confusing to infer beef palatability when yield and quality attributes are used in grading and classification systems. Thus minimizing the concurrent use of beef yield and quality attributes when valuing carcasses in current systems could be worthwhile. Alternatively, ideas could be borrowed from the USDA system, which has separate grading systems for quality and yield, or the EUROP beef classification, which focuses on yield. It may also be important to modify current systems in the region, to adapt existing systems or to develop new ones to estimate the value of carcasses.

Current systems in Southern Africa use age as determined by dentition and bone ossification as the primary basis for predicting beef tenderness. Consumers' willingness to pay premiums for beef with guaranteed tenderness is well documented (Verbeke et al., 2010; Reicks et al., 2011). As a result, the primary emphasis of most global carcass grading and classification systems is on guaranteeing beef of consistent tenderness in and across grades or classes. Progression in animal age is generally associated with decreased meat tenderness, which is triggered by the increased concentration of insoluble collagen (Warris, 2010). Meat from younger animals has more soluble collagen, and consequently is more tender than that of older animals (Warris, 2010). Namibia, South Africa, Botswana, and Zimbabwe place desirable grades and classes on carcasses from young animals (0-2 permanent incisors). In Malawi, carcasses with 
up to six incisors are considered for top beef quality grades. Similar carcases from six-toothed animals are put in low or inferior classes and grades in systems that emphasize young animals. It has emerged that such systems that emphasize young animals do not accurately predict the beef tenderness of slow-growing African indigenous cattle with three to six incisors that are often finished off pasture (Strydom, 2011). Contrary to the proven trend that tenderness declines with age from 0-2-toothed, through 3-6-toothed, to 78 toothed cattle for grain-finished animals (Warris, 2010), 3-6-toothed pasture-finished cattle have been reported to have more tender beef than 0-2-toothed pastured animals (Strydom, 2011). The tougher meat reported for 0-2-toothed pastured animals could be related to poor conditioned small carcasses that reflect poor growth rates (Strydom, 2011), which could be addressed by improving pasture condition. Shackelford et al. (1994) and Perry \& Thompson (2005) reported more tender meat for faster growing animals in the same group, which Shackleford et al. (1994) related to lower calpastatin activities, and consequently better ageing ability of muscle.

Besides age and production systems, differences in tenderness could be caused by other preslaughter factors, including differences between cattle breeds (genetic), pre-slaughter stress and growthenhancing technologies (Frylinck et al., 2015; Strydom et al., 2015). Variation in tenderness at shelf level is also a function of the amount of ageing of meat (Polkinghorne \& Thompson, 2010), among other postabattoir practices that are not covered by any classification system, including electrical stimulation and hanging. These factors compromise the accuracy of using age to predict tenderness. As a result, consumers suffer because of poor information provided by the retailer, causing lack of trust in the final product (Webb, 2015). Use of dentition as the only proxy for beef tenderness does not accurately describe the attribute when breed, growth promotants and post-mortem manipulations are considered. Even when this system is regarded as unbiased, it fails to support large-scale production requirements as it is tedious, costly and time consuming (Craigie et al., 2012). It is also questionable whether consumers see the classification and, if they do, whether they understand what it means. Breed, ecotype, growth promotants and post-slaughter manipulations, however, have never been considered in grading and classification systems in Southern Africa. Owing to a significant level of crossbreeding in the region, breed factor may be difficult to describe in these systems, but could be viable for indigenous cattle breeds finished off natural pasture (Strydom et al., 2015). Generally, 0-2-toothed young cattle from feedlot are implanted or dosed with hormonal growth promotants and beta-agonists, which affect meat tenderness negatively (Strydom et al., 2011; Frylinck et al., 2015). Consequently, young cattle do not show differences in meat tenderness in low connective tissue muscles compared with older grass-fed cattle (Crosley et al., 1994; Thompson et al., 2010; Strydom et al., 2015). Research to determine better criteria for predicting tenderness than age are therefore important. These could include the use of proteomics (Moloto et al., 2015), visual observation of structural properties (Modika et al., 2015), measurement of the hump (Rhomboideus muscle), which is linked to the $B$. indicus breeds and their genetic deposition to higher levels of calpastatin (Strydom et al., 2016) and building models to explain differences and use them to develop technologies to standardize meat tenderness (Frylinck et al., 2015).

There are contrasting positions over what constitutes the optimal level of beef carcass fatness among Southern African countries. Countries such as Botswana, Namibia, and South Africa prefer low carcass fatness, while Malawi and Zimbabwe prefer fatter carcases. Botswana's preference for low carcass fatness is probably influenced by its long participation in international beef trade (Ransom, 2011) characterized by a decline in proportions of consumers preferring fat beef cuts (Ngapo \& Dransfield, 2006). South Africa's push for beef carcasses with low fat is possibly driven by socio-economic factors, including an increasing population of consumers with high disposable incomes that seek healthier foods (Schönfeldt et al., 2016). Contradictory fatness preferences have implications for the grading and classification of indigenous cattle finished off natural pasture. In Botswana, Namibia, and South Africa, indigenous cattle finished off natural pasture would be desirable because of their lean carcasses. In contrast, in Malawi and Zimbabwe, beef from such animals would be less preferred. Instead of valuing beef based on fat content alone, recent evidence calls for the grading and classification to be based on content and fatty acid composition (Mapiye et al., 2012; De Smet \& Vossen, 2016). Although the practicality of measuring fatty acids may be an obstacle, near-infrared spectroscopy (NIRS) online technology (Prieto et al., 2013) could be used in high-throughput abattoirs. Such information could be particularly important for health-conscious consumers. Carcass fat content and fatty acid composition affect organoleptic properties (i.e. juiciness, flavour and tenderness) and healthfulness of beef (O'Quinn et al., 2012). Therefore, new carcass grading and classification systems must consider valuing beef in terms of content and fatty acid composition without compromising organoleptic quality or healthfulness.

Another shortcoming is that carcasses from indigenous cattle finished off natural pasture receive poor conformation classes or inferior grades. In fact, carcasses from indigenous cattle do not compete favourably with those derived from exotic breeds owing to their inherent small and compact bodies (Soji et al., 2015). In 
addition, conformation in the region is assessed subjectively using visual scores of body shape profiles. Overall, current grading and classification systems in Southern Africa indicate that there are numerous combinations of age, fat and conformation classes in which carcasses can be classified or graded. In South Africa for example only 5 to $10 \%$ of the carcass classification system is used effectively, notably classes A2, A3, AB2, AB3, while small proportions of carcasses are classified in other categories (Webb, 2015). This phenomenon arises partly because most of the cattle traded in the formal market come from feedlots and are therefore young and have good subcutaneous fat cover. There is also evidence of increased variation in carcass grading and classification categories. This is attributed to differences between cattle breeds, different animal production systems, and the use of modern feedstuffs and growth-enhancing technologies (Webb, 2015). The wide range of grading and classification criteria and variations in categories might be predisposing factors for dissatisfaction among stakeholders in the meat production-to-consumption continuum since they may not be capable of embracing diverse breeds and production characteristics and their influence on beef palatability.

In the current systems, carcass weight may be considered at the same level as age in terms of inappropriate description of carcasses from indigenous cattle. Indigenous cattle are not preferred in the feedlot system because they are slow growing, have light bodyweight and small frames (Strydom, 2008). In general, feedlots target fast-growing, medium- to late-maturing breeds with heavy weight and large frames. In South African feedlots for example beef cattle are fed to an average target slaughter weight of 300-450 $\mathrm{kg}$, which give target average carcass weights of 180-250 kg (Strydom, 2008; Haasbroek, 2013; SAFA, 2015). It is almost impossible for indigenous breeds to achieve an average carcass weight of $180-260 \mathrm{~kg}$ when they are less than 36 months old (0-2 toothed). Typically, indigenous cattle are kept longer in the feedlot or marketed at an older age if finished off natural pasture to gain more weight (Strydom, 2008). Indigenous cattle become less profitable when kept for a long period in the feedlot as they mature early, thus gain less weight, and deposit more fat. With the current drive towards heavier carcasses in South Africa, this is going to become an even bigger problem and indigenous cattle may become less suitable for meeting market demand. In terms of grading and classification, Malawi is probably the only country in Southern Africa that grades carcasses based on weight, in which carcasses $(>180 \mathrm{~kg})$ are preferred. Age categories in Malawian grading systems were probably crafted to suit the slow-growing small-framed Malawian zebu (Dzanja et al., 2013), which are ready for slaughter off natural pasture at the age of 36 to 48 months (Butterworth \& McNitt, 1994). Unfortunately, by the time the indigenous breeds are finished, they have 7-8 permanent incisors and qualify for choice or prime grades (Nkhonjera et al., 1988).

Carcass fat colour is one of the criteria that are used in Malawian and Botswanan grading systems. Carcasses covered with white fat are valued more than those covered with yellow or creamy fat. The motivation for discriminating against yellow fat was probably aimed at promoting feedlot beef production to meet increased domestic demand for beef and beef products (Ransom, 2011). However, there is not sufficient local evidence that consumers prefer white fat to yellow fat in Southern Africa. In fact, yellow or creamy fat colour in a healthy bovine is a result of a high intake of carotene and is characteristic of carcasses from pasture-raised cattle (Dunne et al., 2009). Negative discrimination of carcasses based on yellow fat does not favour indigenous cattle. In fact, a positive discrimination of yellow fat should be promoted because beef from pasture-finished animals has many human health benefits (Scollan et al., 2014; Van Elswyk \& McNeill, 2014). It is thus important to describe fat colour appropriately in future carcass classification systems. It may also be relevant to distinguish between pasture-and grain-fed animals, especially when other quality characteristics are considered, such as meat fatty acid composition, flavour, juiciness, and aroma. Overall, there are great challenges and opportunities for the Southern African beef industry, which is under pressure to improve production efficiency while maintaining or improving quality traits desired by consumers. At the same time, opportunities to enter new world markets are expanding and these markets come with different consumer expectations.

\section{Opportunities for improving beef carcass grading and classification systems in Southern Africa}

The use of subjective methods in grading and classification systems for assessing the value of beef carcasses is often the cause of distrust among players in the meat industry globally (Craigie et al., 2012). Use of manual inspection is not reliable because it is difficult to demonstrate objectivity as long as human classifiers are involved (Allen, 2014). In addition, some systems have sophisticated standards, training, certification and audit processes, which improve the objectivity of manual grading and classification. It is against this background that high-technology solutions are being sought to use machine vision for quality, timely assessment and accurate valuation of agro-based products (Alfatni et al., 2013). There is an opportunity to improve the prediction of meat quality characteristics, and obtain additional value from mature carcasses through advanced machine-based technologies such as grade cameras, dual energy X-ray 
absorptiometry and spectroscopic methods, including NIRS, Raman spectroscopy, and hyperspectral imaging (Aalhus et al., 2014). Meanwhile, video image analysis (VIA) and hyperspectral imaging, which uses a combination of VIA and NIRS, are becoming popular in meat classification systems (Naganathan et al., 2015). In VIA, digital video images of carcass sides or cuts are taken and processed in software to generate output variables, which are then evaluated for their relationship to meat quality attributes (Vote et al., 2003). The best opportunities for improving computer vision solutions lie in hyperspectral imaging (HIS), which provides additional information about meat composition and structure. HSI, coupled with multivariate analyses, could be used for rapid and accurate prediction of meat quality parameters such as colour, tenderness, marbling, water-holding capacity, drip loss and pH (Cheng et al., 2015). In addition, HSI could be used in classification and discrimination of muscle types (Cheng et al., 2015). Robust NIRS online technology for predicting the content and composition of fatty acids, represents another opportunity (Prieto et al., 2013). The future incorporation of this technology into automated grading and classification and data collection systems will allow the possibility of health-conscious marketing, beyond grass-finishing value chains (Aalhus et al., 2014). Therefore, advanced technologies could be used as augmentation tools for objective valuation and standardization of beef carcasses in Southern Africa. Advanced technologies such as HSI might be more important to high-throughput abattoirs than low-throughput ones. Low throughput abattoirs may work towards implementing small cost-effective grade cameras and VIA systems, which use a camera with special lighting to photograph and estimate carcass traits such as fat thickness. However, in any regional structure, all abattoirs should use the same classification system, and the cost of more modern technologies may be a limiting factor for the introduction of such systems.

Biotechnological tools that are applicable to meat production include analysis of single nucleotide polymorphisms (SNPs), proteomics and metabolomics. These tools identify biomarkers (genes, proteins, and metabolites), whose expression level or abundance is associated with a phenotype of interest, such as the quality of meat (Hocquette et al., 2014). SNP biomarkers are used to predict meat quality attributes from birth, while protein and metabolite biomarkers are used to predict meat quality after slaughter (Picard et al., 2015). Gene and protein expression profiling of bovine muscles has revealed that the expression level of many genes and the abundance of many proteins could be indicators of muscle mass, tenderness, flavour and marbling of meat (Viegas et al., 2014). Therefore, genomic, proteomic and metabolomic approaches could be used to value beef carcasses and meat cuts for specific markets. Markers for beef tenderness are now well known, including those of African indigenous cattle. For example, Moloto et al. (2015) showed protein expression changes in response to ageing associated with beef tenderness in Nguni cattle. The major gap in Southern Africa's carcass classification is lack of accurate criteria for describing beef quality attributes, especially tenderness. Proteome and metabolite-based markers could fill the gap. Although these approaches are expensive and require highly skilled technical expertise, the advance of rapid methods through collaboration with developed countries could be feasibly be implemented in Southern African highthroughput slaughterhouses in the short to mid-term.

Overall, consumers in Southern Africa have limited understanding of the use and significance of beef grading and classification systems (Vermeulen et al., 2015; Schönfeldt et al., 2016). This is probably because these systems are more producer than consumer centred (Vermeulen et al., 2015). Knowledge of physical meat traits such as tenderness, fat cover and conformation, which are emphasized in current Southern African systems, gives limited information to consumers about expected eating quality compared with the ageing period, feeding regime (grass versus grain and use of growth promotants) and even the slaughter process (Vermeulen et al., 2015). Stakeholders (i.e. education and research institutions, health professionals, policy makers, consumer associations, animal protection societies, and the media) must educate producers, retailers and consumers and help them to understand production, quality, safety, and ethical issues related to beef production and the importance of beef grading and classification systems. Carcass grading and classification schemes constructed according to consumer preferences easily achieve wide acceptance in any beef industry (Polkinghorne \& Thompson, 2010). It is also crucial to re-align the current grading and classification systems with consumer preferences.

Perceptions of and expectations about beef quality and eating experience are not the same among consumers, even from the same country (Olivier et al., 2009). In Southern Africa in general, white African consumers prefer more tender beef, while black African consumers, particularly those that live in rural areas, prefer beef that is chewy, flavoursome and juicier (Thompson et al., 2010; Ransom, 2011). Consumer decisions to purchase beef are influenced by appearance characteristics (muscle, fat and bone ratio, colour of lean and fat, and lack of defects). The eating quality of the cooked meat (flavour, juiciness, tenderness) (Smith et al., 2008) influences subsequent purchases. In most cases, consumers concentrate on flavour to ultimately establish when beef tenderness is acceptable to them (Aalhus et al., 2014). Thus, flavour is a decisive sensory trait that affects consumer satisfaction in beef. Although cattle finished off natural pasture may not have a perceived superior value based on the existing grading and classification systems, they may 
have other quality attributes that are of value to the consumer - such as flavour - that are not considered in these systems. This creates an opportunity to include meat eating quality as a supplementary grouping to mainstream carcass classification systems (Matthews, 2016). The same line of reasoning was adopted by Polkinghorne et al. (2008) when they developed the MSA beef grading system, which seems to hold most potential for implementation in South Africa.

Unlike existing beef grading and classification systems in Southern Africa, which use a carcass as the basic unit, the MSA system predicts consumer satisfaction from a cooked meal for each cut of the carcass (Polkinghorme \& Thompson, 2010). The system considers pre-slaughter and post-slaughter factors to attain a palatability score (Polkinghorme et al., 2008). Pre-slaughter factors include breed, weight for age and growth rate, hormonal growth implants, fatness, marbling, gender, stress and management practices. Postslaughter practices include $\mathrm{pH}$ and temperature paths, hanging, ageing, and cooking method. Overall, the MSA scheme is less about carcass description and more about quality assurance and conditions in the abattoir. Thompson et al. (2010) tested the MSA system in South Africa, and found that beef from indigenous cattle classified using this system met consumer eating quality expectations on the same level as that from exotic breeds. More importantly, Thompson et al. (2010) noted that while the increased connective tissue toughness from older indigenous animals was a problem with grilling, it was suited to the slow cooking methods commonly used by black African communities. These authors reported that beef cuts from the older lighter indigenous cattle finished off pasture and prepared with slow cooking methods were preferred by black African consumers. Based on these considerations, the opportunity to develop a flavour niche market might be achieved by utilizing indigenous breeds owing to their slow maturing and exposure to natural pasture. As a result of its success when tested locally, the MSA quality system has been considered for use in South Africa (Strydom et al., 2015).

Although beef value lies in the eye, mouth and mind of the consumer (Aalhus et al., 2014), at present producers in Southern Africa are rewarded by carcass grade or class instead of eating quality. Southern Africa is experiencing rapid urbanization and consumers with high disposable income are willing to pay for credence and measureable quality differences (Schönfeldt et al., 2016). Credence quality traits refer to beef quality attributes that cannot be evaluated under normal circumstances by the average consumer, becoming a matter of faith and trust in the information (Grunert et al., 2004). Credence quality is important to consumers in terms of rising concerns about health, safety, origin, animal welfare and sustainability (Warriss, 2010). In South Africa for example affluent consumers are demanding healthier animal foods produced in a sustainable manner with higher standards of animal welfare (Schönfeldt et al., 2016). The expanding middleclass consumers, with a high affinity for animal-based protein sources, are increasingly emulating this type of behaviour, with less affluent consumers expected to follow suit in the near future (Marandure et al., 2016).

The major health concern about beef is consumption of high proportions of saturated fatty acids and trans-fatty acids, which have been associated with cardiovascular disease, diabetes, and several cancers (Mitchell et al., 2012; De Smet \& Vossen, 2016; Ruiz-Núñez et al., 2016). However, consuming beef from grass-fed animals could reduce these risks as it contains human health beneficial fatty acids (e.g. vaccenic acid, rumenic acid, omega-3 fatty acids), $\beta$-carotene, and $\alpha$-tocopherol in greater proportions than grain-fed beef (Daley et al., 2010; Van Elswyk \& McNeill, 2014; Scollan et al., 2014). Until now, natural pasture finished animals have been imprecisely and non-verifiably identified in the current system through the presence of yellow fat and their market potential is not being realized. Smallholder farmers raising cattle on natural pasture, who are currently disadvantaged by grading and classification systems, may benefit from classification or labelling and niche marketing of natural pasture-fed beef.

Another concern regarding consumption of beef is safety, which is centred on the use of non-forage feed supplements, acaricides, anthelmintics and growth promotants, including hormones and antibiotics (Dunshea et al., 2014). These chemicals are linked to the risk of cancers, worm and microbial resistance to antibiotics, among other undesirable issues (Warris, 2010). Under natural pasture-based production systems in Southern Africa, indigenous beef cattle are produced with minimal or no use of biocides (Muchenje et al., 2008; Mapiye et al., 2011). Globally, information about hormones, antibiotics, traceability-enabled and bovine spongiform encephalopathy (BSE) tested beef have been associated with willingness to pay a premium for meat (Viegas et al., 2014). However, current grading and classification systems do not distinguish between beef production that are enhanced with chemicals (e.g. growth enhancing technologies) and naturally produced beef. Where the information is provided through labelling, it is a question of faith and trust (Viegas et al., 2014). Therefore, efforts should be made in Southern African carcass classification and meat labelling schemes to distinguish between growth promotant-based beef and natural beef, which again may promote smallholder natural pasture-based beef production systems.

Humanely raised and slaughtered beef is another trend that is focused on a segment of consumers that are ready to pay a premium for meat that has been produced under prescribed standards (Aalhus et al., 2014). Current research shows that stress-free livestock that are allowed to express their natural behaviour 
are healthier (Horgan \& Gavinelli, 2006), thus more productive in terms pf quantity and quality. Development of on-package labelling for certified animal welfare standards throughout the production process could be crucial. However, as Webster (2001) notes, even though producers are responsible for providing animal welfare, there are costs associated with implementing higher animal welfare standards, such as those related to training farm staff, and adapting farm activities to appropriate standards (Viegas et al., 2014). Another problem is that, to date, there is no single definition of 'humane meat'. In addition, it would be particularly difficult for smallholder producers to certify humane beef, and easier for large commercial producers. Thus humane certified labelling of beef may prove a disadvantage to smallholder producers. However, the main idea behind the humane meat movement is that people will continue to eat meat for the foreseeable future, but farming practices deemed to be inhumane could be eliminated (Freeman, 2010). In addition to animal welfare, some consumers are worried about the consequences of beef production on the environment and the economic status, social life and cultural heritage of producers (Tallontire et al., 2001). Research should contribute to effective and informative labelling of animal welfare information on products to enhance informed decision making, transparency, and eventually the likelihood of consumers choosing animal welfare-enhanced beef products.

Overall, beef healthfulness, safety, animal welfare and sustainability are often jointly produced. Extensive natural pasture-based production systems of indigenous cattle breeds are often considered more sustainable in terms of carbon sequestration, utilization of unproductive land and conversion of fibre to food, and provide higher standards of animal welfare, each linked to healthier, safer and more flavoursome beef (Marandure et al., 2016). Nguni cattle for example, owing to their adaptability (i.e. drought and heat tolerant, disease and parasite resistant), can be raised on natural pastures with little or no acaricides and anthelmintics, and no growth enhancers, and produce safe health-promoting high-quality beef (Muchenje et al., 2008; Mapiye et al., 2011). A combination of indicators related to beef nutritional and sensory quality, environmental sustainability considerations (e.g. carbon footprint, water footprint, animal welfare, ecological biodiversity), economic efficiency (i.e. income of farmers and of other stakeholders of the supply chain, and rural development) and producers' social sustainability (e.g. gender equity, social life and cultural heritage) would allow prediction of the overall quality of beef, mainly for consumers, but also for stakeholders in the supply chain (Van Ittersum et al., 2007; Hocquette et al., 2014). Credence quality attribute information could be indicated on meat through an on-package labelling system. A clear labelling system may be used as a mechanism for differentiation to enable heterogeneous consumers to purchase traits they desire. It could be important to assess whether the price premium consumers are willing to pay for these beef credence attributes is sufficient to offset production costs. Research to identify segmentation variables and corresponding consumer segments is warranted because there are probably niche markets for various combinations of credence quality attributes. Undertaking this segmentation based on socio-demographic profiles could help capitalize on consumers' heterogeneous preferences by showing new market opportunities for beef differentiation.

\section{Towards a regional carcass classification system}

Carcass grading and classification systems in Southern Africa, like other global classification systems, are limited in that they can describe only those attributes that are measurable or detectable on the day of slaughter or, at most, the day after (Strydom et al., 2015). In addition, most of the properties that are described or scored in a grading or classification system are indirect measurements of traits such as age, which is recorded as a number of permanent incisors, while fat and conformation are based only on visual appraisal of fat content and muscularity or edible yield, even when assessed by a trained classifier with photographic references (Webb, 2015). Nor do the current systems describe ultimate beef palatability, which is influenced mostly by post-abattoir practices. In addition, many of the descriptive terms used in the current grading and classification systems are vague, subjective, and sometimes meaningless. More importantly, current grading and classification systems in the region are faulted for their emphasis on younger and heavier carcasses from fast-growing exotic breeds, as opposed to older and lighter carcasses from slowgrowing indigenous cattle that are ideally suited to being finished off natural pasture. It is essential to the system that the attributes that are evaluated during classification should reflect the interests of the people who want to trade in the product, and that the evaluation itself is totally consistent and repeatable. The deficiencies of current systems in describing the carcasses of indigenous cattle finished off natural pasture may be addressed through the development of a common carcass classification for the region. A common stand among countries in Southern Africa would go a long way towards pushing for standardization of the criteria that appropriately describe carcass yield and meat eating quality of indigenous and exotic cattle breeds under local production systems.

Suggestions to be considered in the common carcass classification would include a total regional movement from a grading system to a classification system. The ranking of beef in grading systems often 
gives the impression that beef with low palatability has no value, yet such carcasses may be ideal for manufacturing certain products and for other consumers (Fisher, 2007). In addition, beef that is considered of low palatability by grading systems may meet the requirements of certain ethnic groups. Unfortunately, peer-reviewed evidence is limited, but anecdotal evidence suggests that this may be applicable in Southern Africa and warrants further research. The current South African, Namibian and Zimbabwean beef carcass classification systems have quality ranking connotations in their classes (A, B and C). Owing to the use of preferred classes, the Namibian and South African classification systems are used as grading systems, which defeats the original purpose of a classification system. The proposed regional classification should not have quality connotations. Perhaps the classes would have to bear the SADC acronym like the EUROP classification system.

Agreement would have to reached as to whether to use dentition and bone ossification or weight for age and growth rate, as in the MSA system, to assess carcass maturity. However, there is a poor relationship between shear force or sensory panel tenderness of the loin muscle and age classified according to dentition (Lawrence et al., 2001). Inconsistencies of shear force and sensory panel tenderness of the loin muscle and age classified according to dentition were shown in South African beef carcass classification when production system was considered (Strydom, 2011; Webb \& Erasmus 2013). On the other hand, in systems that use the bone ossification method to assess carcass maturity, including the USDA grading system, mature cattle are classified more appropriately by including marbling to compensate for maturity deficiencies (Polkinghorne \& Thompson, 2010). However, this trade-off would have to be considered carefully, since at present marbling is not considered in most grading and classification systems in the region.

The regional classification would have to predict the ultimate beef eating quality or experience. This could be achieved by modifying the MSA, as suggested by Strydom (2011). Marbling for example has to be revised to cut down on beef fat level if the MSA system is to be adopted. Although there are differences in fat preferences between and within countries, the common system could borrow this argument for cutting down fat levels, as high levels of fat in meat are perceived to be unhealthy. Strydom (2011) was cautious about adapting the South African classification system to the MSA, in spite of its inadequacy in defining the beef eating quality of indigenous and exotic breeds. This author argued that the MSA system is more expensive and requires higher technical skills, better organized infrastructure and improved traceability compared with the present systems. The starting point could be giving MSA licences to high-throughput abattoirs and those that are interested in exporting beef in Southern African member states, as suggested by Strydom (2011). Similarly, abattoirs that are interested in using advanced technologies for classifying carcasses would be encouraged to use of the objectivity and convenience of technology to support large-scale production.

It could be important to have a classification system that awards value to different types of production systems. Information about beef that may not be included in the classification system - including credence quality attributes and some post-slaughter treatments - should be conveyed to the consumer through an onpackage labelling system. In practice, standard post-slaughter treatments would be defined from time to time. The label need only indicate deviations from this standard, as suggested by Price (1982). In Canada for example an alternative approach is used in which labelling at retail outlets incorporates best cooking practices for a particular cut in the label to assist consumers with limited cooking background (Canada Beef Inc., 2011). Labelling information would be vital to consumers, ensuring repeatability of eating quality, while the classification information would be crucial to people in the meat production-to-consumption continuum. A clear and adequate meat labelling system could improve consumer confidence, cultivate positive attitudes, and ensure that meat satisfies consumer expectations, demands and needs (Font-i-Furnols \& Guerrero, 2014). Such labelling could increase the competitiveness and market share of beef from the region. Credence quality attribute claims and labelling systems are perceived as credible when they are supported by authorities that are trusted among the public (Ingenbleek \& Immink 2010). Research should therefore provide objective methodologies to develop accurate indicators to predict credence quality traits of beef.

A common beef carcass classification system in the region would ensure easy trade facilitation between member states. In addition, it could facilitate international trade in which it is beneficial for member states to combine forces in search of better markets and to bargain collectively for improved trade terms and conditions. A regional effort through a harmonized beef carcass classification system could help to conserve indigenous cattle genetic resources, which are rapidly being lost through crossbreeding and breed replacement. The use of a single system could help to foster technical cooperation in livestock production among member states. From a resource-based perspective, developing marketing strategies based on regional attributes may provide the smallholder beef sector with a competitive advantage (Haucap et al., 1997). By using a common regional classification system, marketers in member states would be able to exploit consumer associations and provide a product with a regional image. Together with specific beef 
product qualities, this image could create a unique identity for the regional beef products and in this way add value to beef (Steiner, 2004).

Despite the benefits, attempts to develop a common carcass classification system are often resisted owing to entrenched opinions and priorities between and within countries (Price, 1995). Development of a common classification for Southern Africa is likely to face challenges including wide differences among beef industries in technological advancement and consumer preferences. However, a common carcass classification scheme might foster active cooperation among countries, thereby satisfying regional consumers and the international market (Polkinghorne \& Thompson, 2010). To minimize resistance to such a system, it should be crafted in such a way that it is flexible and applicable to a variety of consumers and conditions. In Europe for example the EUROP system allows each country to expand or collapse the levels on a particular class (Fisher, 2007). Another option for minimizing resistance is to develop a basic regional classification system that could be used for price formation with supplementary descriptive systems to differentiate product quality. Such descriptive quality systems could be initiated and implemented by producers, abattoirs and retailers and audited by independent organisations. Certainly, the development of a unified carcass valuation system for the region could be a long and costly process for the beef industry. It could therefore be important to estimate the costs and benefits associated with development and implementation of the new system before a decision is made. That would give the beef industry an opportunity to establish a more flexible and less costly classification system.

\section{Conclusions}

Current beef carcass grading and classification systems in Southern Africa value indigenous cattle inappropriately, which are ideally suited to being marketed off natural pasture. In addition, the principal criteria used to estimate carcass yield and quality are measured indirectly and subjectively and do not predict beef palatability accurately. There are opportunities to improve the prediction of carcass yield and quality, including the use of biotechnology and machine-based technologies, and obtain additional value from carcasses of indigenous cattle breeds finished off pasture. There is also an opportunity to develop credence quality attribute-based niche markets that take advantage of the adaptability of indigenous breeds and benefits of natural pasture-based production systems. Establishing common consumer-centred beef carcass classification and labelling systems that accommodate diverse breeds and production systems in the region could satisfy local and international markets.

\section{Acknowledgements}

The authors gratefully acknowledge Ms Zimkhitha Soji of University of Fort Hare, Alice, South Africa, Drs Michael E.R. Dugan and Jennifer L. Aalhus of Lacombe Research and Development Centre, Lacombe, Canada, and Prof Mick Price of University of Alberta, Edmonton, Canada, for critically reviewing this manuscript. Mr G. Chingala gives special thanks to the Royal Norwegian Kingdom through the Royal Norwegian Embassy in Malawi for providing his PhD bursary and research grant. Dr C. Mapiye and Prof K. Dzama acknowledge funding provided by the Department of Science and Technology-National Research Foundation (DST-NRF) Centre of Excellence (CoE) in Food Security (grant no. 140102) and NRF (Research and Technology Fund) (grant no. 98704).

\section{Authors' Contributions}

GC wrote the review with input and editorial assistance of $\mathrm{CM}, \mathrm{ER}, \mathrm{KD}$ and $\mathrm{LH}$.

\section{Conflict of Interest Declaration}

The authors declared that there is no conflict of interests.

\section{References}

Aalhus, J.L., López-Campos, Ó., Prieto, N., Rodas-González, A., Dugan, M.E.R., Uttaro, B. \& Juárez, M., 2014. Review: Canadian beef grading - Opportunities to identify carcass and meat quality traits valued by consumers. Can. J. Anim. Sci. 94, 545-556.

Alfatni, M.S.M., Shariff, A.R.M., Abdullah, M.Z., Marhaban, M.H.B. \& Saaed, O.M.B., 2013. The application of internal grading system technologies for agricultural products - Review. J. Food Eng. 116, 703-725.

Allen, P., 2014. Beef carcass classification and grading. Encyc. Meat Sci. Elsevier.

Botswana Livestock and Meat Industries, 2007. Grading of carcasses regulations. Republic of Botswana.

Butterworth, M.H. \& McNitt, J.I., 1994. The Malawi Zebu. World Anim. Rev. Article No. 49.

Cabrera, R., Cochran, M., Dangelmayr, L., D'Aguilar, G., Gawande, K., Lee, J., Speir, I.S. \& Weigand, C., 2010. African capacity building for meat exports: Lessons from the Namibian and Botswanan beef industries. Currents: Int. Trade Law J.19, 55-78.

Canada Beef Inc., 2011. Standard cooking instructions for Canadian beef cuts. http://bic3dev.boldinternet.com/pdf/Standard_Cooking_Instructions_EN.pdf. Retrieved 10 March 2017.

Cheng, W., Cheng, J. H., Sun, D. W. \& Pu, H., 2015. Marbling analysis for evaluating meat quality: Methods and techniques. Compr. Rev. Food. Sci. Food. Saf. 14, 523-535. 
Craigie, C.R., Navajas, E.A., Purchas, R.W., Maltin, C.A., Bünger, L., Hoskin, S.O. \& Roehe, R., 2012. A review of the development and use of video image analysis (VIA) for beef carcass evaluation as an alternative to the current EUROP system and other subjective systems. Meat Sci. 92, 307-318.

Crosley, R.I., Heinze, P.H. \& Naudé, R.T., 1994. The relationship between beef tenderness and age classification in the South African beef carcass classification system. Proc. 40th Int. Cong. Meat Sci. Technol., The Hague, Netherlands SIII.15, 34-35.

Daley, C.A., Abbot, A., Doyle, P.S., Nader, G.A. \& Larson, S., 2010. A review of fatty acid profiles and antioxidant content in grass-fed and grain-fed beef. Nutri. J. 9, 1-12.

De Smet, S.D. \& Vossen, E., 2016. Meat: The balance between nutrition and health. A review. Meat Sci. 120, $145-156$.

Dunne, P.G., Monahan, F.J., O'Mara, F.P. \& Moloney, A.P., 2009. Colour of bovine subcutaneous adipose tissue: A review of contributory factors, associations with carcass and meat quality and its potential utility in authentication of dietary history. Meat Sci. 81, 28-45.

Dunshea, F.R., D'Souza, D.N., Jensen, B.B. \& Engberg, R.M., 2014. Use of antibiotics and growth promotants. Classification of carcasses. Ency. Meat Sci. Elsevier.

Dzanja. J., Kapondamgaga, P. \& Tchale, H., 2013. Value chain analysis of beef in Central and Southern Malawi (case studies of Lilongwe and Chikhwawa districts). Int. J. Bus. Soc. Sci. 4, 92-102.

FAO, 2007. Subregional report on animal genetic resources: Southern Africa. Annex to The State of the World's Animal Genetic Resources, FAO. Rome.

Fisher, A., 2007. Beef carcass classification in the EU: A historical perspective. In: C. Lazzaroni, S. Gigli \& D. Gabiña (Eds), Evaluation of carcass and meat quality in cattle and sheep. EAAP Publication No. 123, Wageningen Academic Publishers. The Netherlands. pp. 19-30.

Font-i-Furnols, M. \& Guerrero, L., 2014. Consumer preference, behavior and perception about meat and meat products: An overview. Meat Sci. 98, 361-371.

Freeman, C.P., 2010. Framing animal rights in the 'Go Veg' campaigns of US animal rights organizations. Soc. Anim. 18,163-182.

Frylinck, L., O’Neil, A., Du Toit, E., Strydom, P.E \& Webb E.C. 2015. The beef tenderness model. S. Afr. J. Anim. Sci. 45 (3), 234-248.

Grunert, K.G., Bredahl, L. \& Brunsø, K., 2004. Consumer perception of meat quality and implications for product development in the meat sector - a review. Meat Sci. 66, 259-272.

Haasbroek, F.E., 2013. The effect of essential oils and calcified marine algae as natural alternatives to ionophore antibiotics on performance of feedlot cattle. MSc thesis, Department of Animal and Wildlife Sciences, University of Pretoria, South Africa. pp. 1-87.

Haucap, J., Wey, C. \& Barmbold, J.F., 1997. Location choice as a signal for product quality: The economics of 'Made in Germany', J. Inst. Theor. Econ. 153, 510-531.

Hocquette, J.F., Botreau, R., Legrand, I., Polkinghorne, R., Pethick, D.W., Lherm, M., Picard, B., Doreau M. \& Terlouw E.M.C., 2014. Win-win strategies for high beef quality, consumer satisfaction, and farm efficiency, low environmental impacts and improved animal welfare. Anim. Prod. Sci. 54, 1537-1548.

Horgan, R. \& Gavinelli, A., 2006. The expanding role of animal welfare within EU legislation and beyond. Livest. Sci. 103, 303-307.

Ingenbleek, P.T.M. \& Immink, V.M., 2010. Managing conflicting stakeholder interests: An exploratory case analysis of the formulation of corporate social responsibility standards in the Netherlands. J. Public Policy Mark. 29, 52-65.

Lawrence, T.E., Whatley, J.D., Montgomery, T.H., Perino, L.J. \& Dikeman, M.E., 2001. Influence of dental carcass maturity classification on carcass traits and tenderness of longissimus steaks from commercially fed cattle. J. Anim. Sci. 79, 2092-2096.

Maciel, S., Amimo, J., Martins, M., Okeyo, A.M., Scholtz, M.M. \& Neser, F.W.C., 2013. Feedlot performance of the Nguni ecotypes in southern Mozambique. Livest. Res. Rural. Dev. 25, 111.

Malawi Meat and Meat Products Act, 1985. Grading of beef carcasses. Chapter 67:02. Laws of the Republic of Malawi.

Mapiye, C., Aldai, N., Turner, T.D., Aalhus, J.L., Rolland, D.C., Kramer, J.K.G. \& Dugan, M.E.R., 2012. The labile lipid fraction of meat: From perceived disease and waste to health and opportunity. Meat Sci. 92, 210-220.

Mapiye, C., Chimonyo, M., Dzama, K., Raats, J.G. \& Mapekula, M., 2009. Opportunities for improving Nguni cattle production in the smallholder farming systems of South Africa. Livest. Sci. 124, 196-204.

Mapiye, C., Chimonyo, M., Marufu, M.C. \& Dzama, K., 2011. Utility of Acacia karroo for beef production in Southern African smallholder farming systems: A review. Anim. Feed Sci. Tech. 164, 135-146.

Marandure, T., Mapiye, C., Makombe, G., Nengovhela, B. Strydom, P., Muchenje, V. \& Dzama K., 2016. Beef traders' and consumers' perceptions on the development of a natural pasture-fed beef brand by smallholder cattle producers in South Africa. Afr. J. Range Forage Sci. 33, 207-214.

Matthews, K., 2016. How does the UK meat industry meet consumer expectations? In: Proceedings of Aldam Stockman's School Programme, South Africa.

Mitchell, P.L., Karakach, T.K., Currie, D.L. \& McLeod, R.S., 2012. t-10, c-12 CLA dietary supplementation inhibits atherosclerotic lesion development despite adverse cardiovascular and hepatic metabolic marker profiles. PLoS ONE. 7, 1-11.

Modika, K.Y., Frylinck, L., Moloto, K.W., Strydom, P.E., Heinze, P.H. \& Webb, E.C. 2015. Visual evaluation of beef tenderness by using surface structural observations and its relationship to meat colour. S. Afr. J. Anim. Sci. 45 (3), 255-262.

Moloto, K.W., Frylinck, L., Strydom, P.E. \& Koorsen, G., 2015. Proteomics approach as a new way to predict tenderness as compared to classical South African Beef Carcass Classification System. S. Afr. J. Anim. Sci. 45, $249-254$. 
Muchenje, V., Dzama, K., Chimonyo, M., Raats, J.G. \& Strydom, P.E., 2008. Meat quality of Nguni, Bonsmara and Aberdeen Angus steers raised on natural pasture in the Eastern Cape, South Africa. Meat Sci. 79, 20-28.

Musemwa, L., Mushunje, A., Chimonyo, M. \& Mapiye, C., 2010. Low cattle market off-take rates in communal production systems of South Africa: Causes and mitigation strategies. J. Sust. Dev. Afr. 12, 5.

Naganathan, G.K., Cluff, K., Samal, A., Calkins, C.R., Jones, D.D., Lorenzen, C.L. \& Subbiah, J., 2015. Hyperspectral imaging of ribeye muscle on hanging beef carcasses for tenderness assessment. Comput. Electron. Agric.116, 55-64.

Naziri, D., Rich, K.M. \& Bennett, B., 2015. Would a commodity-based trade approach improve market access for Africa? A case study of the potential of beef exports from communal areas of Namibia. Dev. Policy Rev. 33, 195-219.

Ngapo, T.M. \& Dransfield, E., 2006. British consumers preferred fatness levels in beef: Surveys from 1955, 1982 and 2002. Food Qual. Prefer. 17, 412-417.

Nkhonjera, L., Agymang, K. \& Butterworth, M.H., 1988. Performance of cattle stall-fed for beef in Malawi. Trop. Anim Health Prod. 20, 155-60.

O'Quinn, T.G., Brooks, J.C., Polkinghorne, R.J., Garmyn, A.J., Johnson, B. J., Starkey, J.D. \& Miller, M. F. 2012. Consumer assessment of beef strip loin steaks of varying fat levels. J. Anim. Sci. 90, 626-634.

Olivier, M.A., Nute, G.R., Font-i-Furnols, M., San Julian, M., Campo, M.M., Sanudo, D., Caneque, V., Guerrero, L., Alvarez, I., Diaz, M.T., Branscheid, W., Wicke, M. \& Montossi, F., 2006. Eating quality of beef, from different production systems, assessed by German, Spanish and British consumers, Meat Sci. 74, 435-442.

Perry, D. \& Thompson, J.M., 2005. The effect of growth rate during back grounding and finishing on meat quality traits in beef cattle. Meat Sci. 69, 691-702.

Picard, B., Lebret, B., Cassar-Malek, I., Liaubet, L., Berri, C., Le Bihan-Duval, E., Hocquette, J.F. \& G. Renand, G., 2015. Recent advances in omic technologies for meat quality management. Meat Sci. 109, 18-26.

Polkinghorne, R., Thompson, J.M., Watson, R., Gee, A. \& Porter, M., 2008. Evolution of the Meat Standards Australia (MSA) beef grading system. Aus. J. Exp. Agric. 48, 1351-1359.

Polkinghorne, R.J. \& Thompson, J.M., 2010. Meat standards and grading - A world view. Meat Sci. 86, 227-235.

Price, M.A., 1982. Meat carcass grading in the future. Can. J. Anim. Sci. 62:3-13.

Price, M.A., 1995. Development of grading and carcass systems. In: M. Jones (ed). Quality and grading of carcass of meat animals. CRC Press, Boca Raton. pp. 174-195.

Prieto, N., Dugan, M.E.R., Lopez-Campos, O., Aalhus, J. L. \& Uttaro, B., 2013. At line prediction of PUFA and biohydrogenation intermediates in perirenal and subcutaneous fat from cattle fed sunflower or flaxseed by near infrared spectroscopy. Meat Sci. 94, 27-33.

Ransom, E., 2011. Botswana's beef global commodity chain: Explaining the resistance to change. J. Rural Stud. 27, 431439.

Reicks, A.L., Brooks, J.C., Garmyn, A.J., Thompson, L.D., Lyford, C.L. \& Miller, M.F., 2011. Demographics and beef preferences affect consumer motivation for purchasing fresh beef steaks and roasts. Meat Sci. 87, 403-411.

Ruiz-Núñez, B., Dijck-Brouwer, D.A.J. \& Muskiet, F.A.J., 2016. The relation of saturated fatty acids with low-grade inflammation and cardiovascular disease. J. Nutr. Biochem. 36, 1-20.

SADC. 2012. Livestock Production. Southern African Development Community. http://www.sadc.int/themes/agriculturefood-security/livestock-production/. Retrieved 19 June 2016.

SAFA, 2016. Beef market indicators. South African Feedlot Association. http://www.safeedlot.co.za/index.asp?Content=151. Accessed 30 June 2016

Schönfeldt, H.C., Pretorius, B. \& Vermueulen, H., 2016. Expectations of different consumer market segments in South Africa. In: Proc. of Aldam Stockman's Sch. Progr., South Africa.

Scollan, N.D., Dannenberger, D., Nuernberg, K., Richardson, I., MacKintosh, S., Hocquette, J.F. \& Moloney, A. P., 2014. Enhancing the nutritional and health value of beef lipids and their relationship with meat quality. Meat Sci. 97, 384-94.

Shackelford, S.D., Koohmaraie, M., Cundiff, L.V., Gregory, K.E., Rohrer, G.A. \& Savell, J.W., 1994. Heritabilities and phenotypic and genetic correlations for bovine post rigor calpastatin activity intramuscular fat content, WarnerBratzler shear force, retail product yield and growth rate. J. Anim. Sci. 72, 857-863.

Smith, G., Tatum, J.D. \& Belk, K.E., 2008. International perspective: characterisation of United States Department of Agriculture and Meat Standards Australia systems for assessing beef quality. Aus. J. Exp. Agri. 48, 1465-1480.

Soji, Z., Chikwanda, D., Chikwanda, A.T., Jaja, I.F., Mushonga, B. \& Muchenje, V., 2015. Relevance of the formal red meat classification system to the South African informal livestock sector. S. Afr. J. Anim. Sci. 45, 263-277.

South African Meat Industry company (SAMIC), 2006. Classification of red meat. www.samic.co.za. Retrieved 12 July 2014.

Steiner, B., 2004. French wines on the decline? Econometric evidence from Britain. J. Agri. Econ. 55, 267-288.

Strydom, P.E., 2008. Do indigenous Southern African cattle breeds have the right genetics for commercial production of quality meat? Meat Sci. 80, 86-93.

Strydom, P.E., 2011. Quality related principles of the South African beef classification system in relation to grading and classification systems of the world. S. Afr. J. of Anim. Sci. 41, 177-193.

Strydom, P.E., Frylinck, L., Van Heerden, S.M., Hope-Jones, M., Hugo, A., Webb, E., Moholisa, E., Liebenberg, B.E. \& Sehoole, O.C., 2015. Sources of variation in quality of South African beef: Case studies in relation to the Red Meat Classification System. S. Afr. J. Anim. Sci. 45, 289-301.

Strydom, P.E., Lühl, J., Kahl, C. \& Hoffman, L.C. (2016). Comparison of shear force tenderness, drip and cooking loss, and ultimate muscle $\mathrm{pH}$ of the loin muscle among grass-fed steers of four major beef crosses slaughtered in Namibia. S. Afr. J. Anim. Sci. 46, 348-359. 
Tallontire, A., Rentsendorj, E. \& Blowfield M., 2001. Ethical consumers and ethical trade: a review of current literature. Policy Series 12. Natural Resources Institute, Chatham, UK.

Thompson, J., Polkinghorne, R., Gee, A., Motiang, D., Strydom, P., Mashau, M, Ng'ambi, J., deKock, R. \& Burrow, H., 2010. Beef palatability in the Republic of South Africa: Implications for niche-marketing strategies. The Australian Centre for International Agricultural Research (ACIAR). The Commonwealth of Australia, Australia.

Van Elswyk, M.E. \& McNeill, S.H., 2014. Impact of grass/forage feeding versus grain finishing on beef nutrients and sensory quality: The U.S. experience. Meat Sci. 96, 535-540.

Van Ittersum, K., Meulenberg, M.T.G, Van Trijp, H.C.M. \& Candel, M.J.J.M., 2007. Consumers' appreciation of regional certification labels: A pan-European Study. J. Agric. Econ. 58, 1-23

Verbeke, W., Wezemael, L. Van, Barcellos, M.D.D. \& Ku, J.O., 2010. European beef consumers' interest in a beef eating-quality guarantee: Insights from a qualitative study in four EU countries. Appetite, 54, 289-296.

Vermeulen, H, Schönfeldt, H.C. \& Pretorius, B., 2015. A consumer perspective of the South African red meat classification system. S. Afr. J. Anim. Sci. 45, 339-354.

Viegas, I., Nunes, L.C., Madureira, L., Fontes, M.A. \& Santos, J.L., 2014. Beef credence attributes: Implications of substitution effects on consumers' WTP. J. Agric. Econ. 65, 600-615.

Vote, D.J., Belk, K.E., Tatum, J.D., Scanga, J.A. \& Smith G.C., 2003. Online prediction of beef tenderness using a computer vision system equipped with a BeefCam module. J. Anim. Sci. 81, 457-465.

Warris, P., 2010. Meat science. An introductory text. 2nd edition. CABI, UK.

Webb, E.C. \& Erasmus, L.J., 2013. The effect of production system and management practices on the quality of meat products from ruminant livestock. S. Afr. J. Anim. Sci. 43, 413-423.

Webb, E.C., 2015. Description of carcass classification goals and the current situation in South Africa, S. Afr. J. Anim. Sci. 45, 229-233.

Webster A.J.F., 2001. Farm animal welfare: The five freedoms and free market. Vet. J. 161, 229-237.

Zimbabwean Carcass Classification Regulations. 2016. Agricultural product marketing (livestock) (carcass classification) regulations. Republic of Zimbabwe. 